\title{
Ethnopedagogical competence of students as a factor in the implementation of the ethnocultural education trend
}

\author{
Andrey Sukhov* \\ Petrozavodsk State University, Petrozavodsk, Russia
}

\begin{abstract}
The purpose of the study is to determine the need to study the ethnocultural trend in national education, its place at the state level, especially as a national-regional component. The author of the article substantiates the reasons and patterns of development of the ethnocultural trend of education in Russia as a multinational country and substantiates its role in formation of national unity due to inclusion of the ethnopedagogical component of training the future school teachers and university teachers in the educational environment. The scientific novelty of the study lies in the contrastive analysis of modern statistics of demographic data, the national composition of the Russian Federation; legislative acts stimulating development of ethnocultural trends in Russia; description of the nationalregional component as a fundamental element in the education system of the Republic of Karelia, clarification of the similarities and differences between the terms "ethnocultural competence" and "ethnopedagogical competence". As a result, the practical experience of the flagship university of Karelia Petrozavodsk State University - is presented as an organization that forms the ethnopedagogical competence of students and a leading platform that implements the principles of ethnocultural education in the system of education and upbringing in the region, indicating examples of ways to develop the ethnocultural trend of education in Russia.
\end{abstract}

\section{Introduction}

In the Russian Federation, the importance of ethnocultural education, understood as "an integral process of studying, active development of ethnocultural heritage and education of the individual on ethnocultural traditions" [1, p. 193], is recognized as the key to the successful functioning of a multinational, multi-confessional and multicultural country. It is clear that the ethnocultural trend in development of national education today is one of the leading ones due to the necessity and importance of obtaining by citizens of the state knowledge about the peculiarities of the cultures of numerous peoples living in Russia. It is this knowledge that can and shall be the basis for the unity of citizens of the state, built on mutual respect, tolerance and intercultural interaction, where development of the ethnocultural component of education and upbringing has always been, is and will be

* Corresponding author: s.andreysuhov@gmail.com 
relevant, because it allows to form and hone the system of behavior of the future personality in society in accordance with the established and accepted traditional values and norms. In this regard, the need for the study of ethnocultures is growing. However, for the successful organization of this process, it is necessary to promote the creation of a cluster of professional pedagogical personnel who possess not only ethnocultural knowledge and skills, but are also capable of transferring similar knowledge and skills to the younger generations, and, therefore, having the skills of conducting ethnopedagogical activities and possessing not only ethnocultural, but also ethnopedagogical competence. Therefore, in the presented aspect, it is important to study the ethnocultural trend in domestic education in order to determine the value of ethnocultural education at the state level, its features as a national-regional component and the role in formation of ethnopedagogical competence in the process of teaching future teachers, education of schoolchildren and students of the universities. In addition, it is important to reveal the significance of these categories in development of the people of Russia.

\section{Study Methods}

The fundamental methods of this study are as follows: contrastive and comparative analysis of modern statistics of demographic data, the national composition of the Russian Federation; legislative acts stimulating development of ethnocultural trends in Russia; the experience of the flagship university of the Republic of Karelia - Petrozavodsk State University - in implementing the trend of ethnocultural education; comparison of data in the field of ethnocultural education and ethnopedagogical training of future teachers and teachers. Also, the study relies on regional, linguocultural, competence-based and multicultural approaches. Methods of generalization and systematization of information are used to structure the studied material.

\section{Results of the Study}

The Russian Federation has historically evolved as a multinational state, therefore, the trend of ethnocultural education has always been and remains relevant for it, since any domestic educational system "shall understand that the communities it serves are plural" [2, p. 296]. That is why in the Russian Federation the national and cultural component of education plays an important role in determining the ways and means of teaching and educating the younger generations of the civilian population.

According to the demographic data of the Federal State Statistics Service (FSGS), 146.7 million people live in the territory of modern Russia (as of 2020) [3], representing more than 190 nations. The titular ethnic group is Russians, who make up $80.9 \%$ of the population of the state (diagram 1). Other major nationalities, according to the FSGS "Socio-demographic portrait of Russia", are: Tatars (3.8\%), Ukrainians (1.4\%), Bashkirs (1.15\%), Chuvash $(1.05 \%)$, Chechens (1.04\%), Armenians (0.86\%), Avars (0.66\%), Mordovians $(0.54 \%)$, Kazakhs (0.47\%), Azerbaijanis (0.44\%), Dargins (0, $43 \%)$, Udmurts and Mari $(0.4 \%$ each), Ossetians (0.39\%), Belarusians $(0.38 \%)$ [4, p. 72] and others. Considering such a vast national picture of Russia, the ethnocultural aspect of education occupies one of the main places in the domestic education system. Its significance is enshrined at the legislative level. 


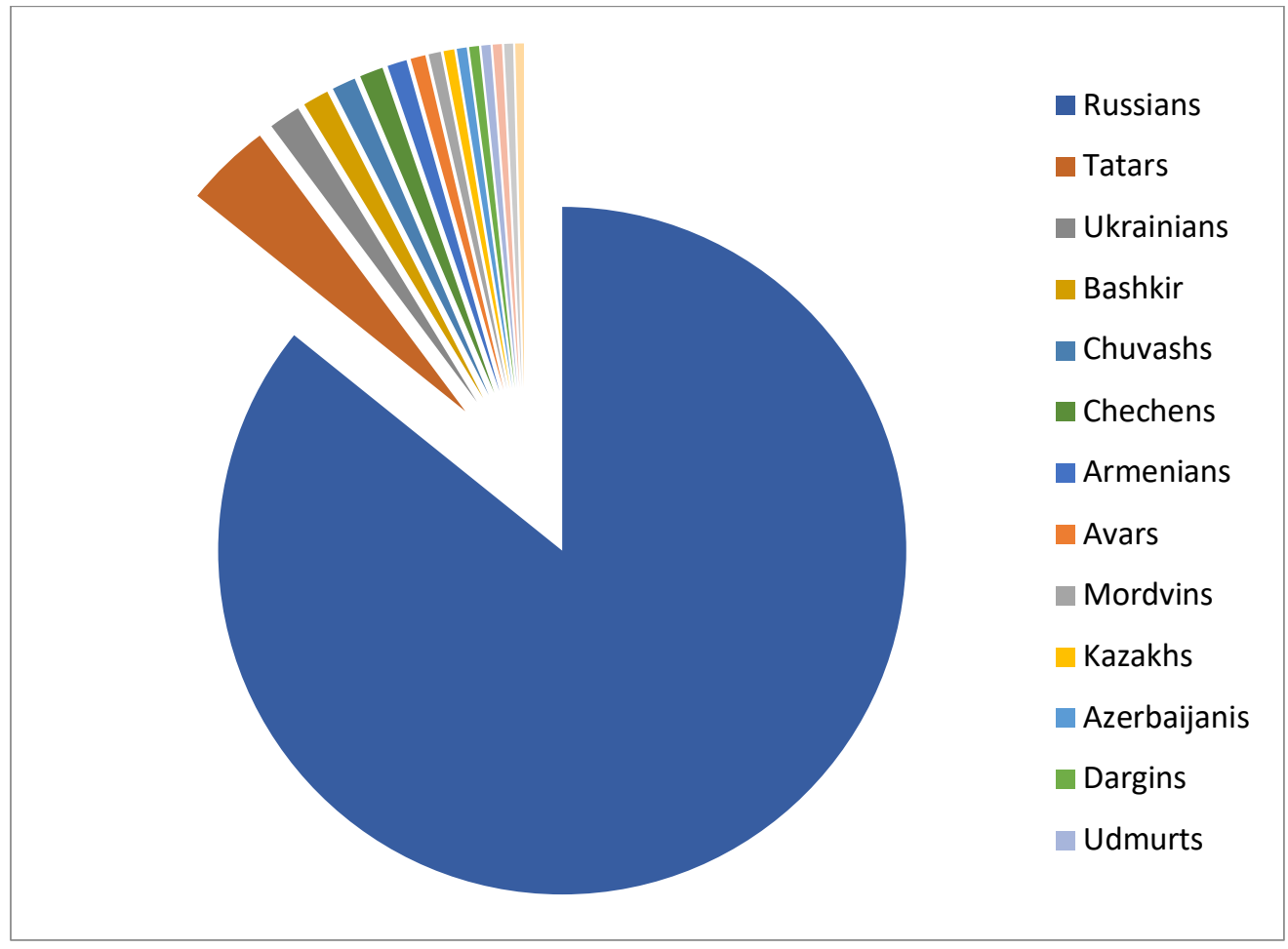

Fig. 1. Largest nationalities of the Russian Federation.

According to the commentary to Article 43 of the Constitution of the Russian Federation, domestic education is designed to "ensure the diversity of educational institutions and the variability of educational programs, the development of the multinational Russian school and the non-state education sector" [5], and the developed state educational standards (SES) must necessarily include "two component: federal and national-regional" [the same]. The main feature is that these components orient the standards towards reflecting in them ideas about the necessary formation of the personal qualities of a graduate who "accepts the values of human life, family, civil society, the multinational Russian people" [6, p. 154]. In this regard, it is important to protect and develop the ethno-cultural characteristics of each nation living in the territory of Russia, which is defined as the principles of state policy and legal regulation by Federal Law No. 273 "On Education in the Russian Federation" [7]. The President of Russia is the guarantor of the observance of these principles, emphasizing the need to preserve "the Russian cultural dominant, which is carried not only by ethnic Russians, but also by all carriers of such an identity, regardless of nationality" [8]. According to N. Afanasyev, S. Panina and R. Egorova, formation of ethnocultural identity is understood as "orientation towards the development and socialization of an individual as a subject of an ethnos and as a citizen of a multinational Russian state capable of self-determination in the context of a modern world civilization" $[9$, p. 274]. The national self-determination of the citizens of the Russian Federation is based on "a cultural code that (...) has survived, (...) [and which] at the same time must be nourished, strengthened and protected. Education plays a huge role here" [8], since it provides ethno-cultural upbringing of the younger generation thanks to the activities of teachers who have ethnopedagogical competence.

The above aspects are taken into account by the national-regional component of the educational system. A.M. Tsirulnikov designates it as an ethnoregional component and notes that in education it expresses such "connection of an ethnic group with a certain place in 
which its historical fate is realized, a way of life grows, which determines the characteristics of education" [10, p. 42]. That is why in Russia it is especially necessary to consider the cultural component in the social environment from the point of view of citizens' belonging to any of the nationalities possessing a unique set of values and traditions formed during the historical development, accepted faith, social norms and everyday life style.

Russian society is quite diverse in terms of the national question and necessarily includes a component of the ethnopedagogical environment. As T.A. Shergina notes, the ethnopedagogical environment "is a part of the social environment that surrounds a person, positively or negatively affects its development and is a set of all living conditions, taking into account the ethnic characteristics of the place of residence, expressed in the mentality of the people, the behavior of people, ethnic traditions, rituals, everyday life, folklore, etc." [11, p. 247]. For Russia, as a multinational and multiconfessional country, creation and care of the maintenance of such an environment is necessary in order to guarantee the preservation of the all-Russian identity, characterized by the aspect of multiculturalism. For this reason, it is especially important to arrange the process of training qualified teachers who have both ethnocultural and ethnopedagogical competencies. The experience gained in the Republic of Karelia serves as an illustrative example of the success of the educational policy of ethnocultural education and ethnopedagogical training of future teachers.

As a part of the Northwestern Federal District of the country, the Republic of Karelia is one of the many multicultural regions of Russia, where representatives of 467 national cultures of the world live. The majority of representatives in the national structure of the population of Karelia are Russians $(82.2 \%)$, followed by citizens of one of the indigenous peoples of the Republic - Karelians (7.4\%), then Belarusians (3.8\%) and Ukrainians $(2.0 \%)$, then again indigenous peoples - Finns $(1.4 \%)$ and Vepsians $(0.5 \%)$, as well as other nationalities $(2.7 \%)$ [12, pp. 157-158] (diagram 2).

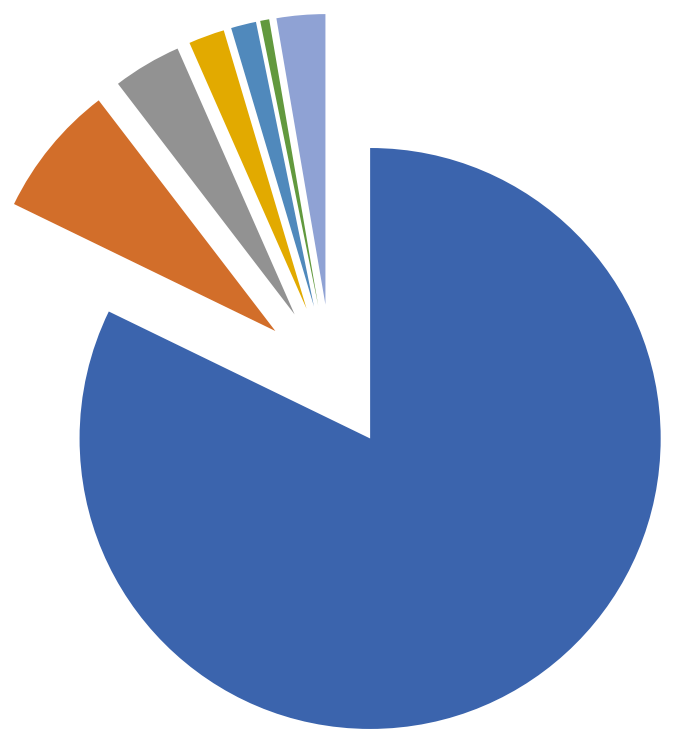

Russians

Karelians

Belarusians

Ukrainians

Finns

Vepsians

Others

Fig. 2. Largest nationalities of the Republic of Karelia.

According to the 2010 census, 45,570 Karelians, 8,577 Finns, 3,423 Vepsians lived in the Republic of Kazakhstan [13]. As shown by a qualitative and quantitative comparison of statistical data since 1989, these indicators have significantly decreased. So, in 1989 the number of Karelians was $10 \%$ of the total number of inhabitants of Karelia, and by 2010 
this figure had decreased to $7.4 \%$, that is, by $2.6 \%$. The reasons for this decline are the socio-economic factors of the development of Russia, which the country faced in the period 1990-2000s, and the related ignorance of the problems with the policy of preserving the cultural heritage (language, literature, crafts, traditions, education) of small indigenous peoples of the Republic of Karelia, which differs markedly from the current changes.

Beginning of an active policy of preserving the indigenous ethnic groups of the Republic of Karelia was laid due to the realization that the small indigenous peoples of the constituent entity of the Russian Federation are carriers of "ritual differences developed over the centuries, associated with moral, ethical and aesthetic primordial values that make up the backbone of the existence of the ethnos" [14, p. 4] and capable, when entering into a dialogue with other cultures, to introduce new content into them and to mutually enrich themselves. First of all, on March 19, 2004, Law of the Republic of Kazakhstan No. 759-ZRK "On State Support of the Karelian, Vepsian and Finnish Languages in the Republic of Karelia" was adopted, since they "constitute the national heritage" [15] of the region. As M.I. Bagautdinova notes that such an initiative to start protecting ethnic groups from extinction in terms of preserving their languages is connected with the fact that "the revival, preservation of ethnic culture and the development of polyculturalism in modern conditions becomes possible only if the central themes of culture of an ethnic group, (...) - language" [16, p. 110]. For this reason, in the Republic of Karelia, the Karelian, Finnish and Vepsian languages are currently recognized as national ones, and implementation of the law is carried out "through the education system", that is, it is entrusted to Karelian schools and higher educational institutions, by calling their activities to use the ethnic culture of indigenous peoples "in everyday teaching practice" [the same].

Higher educational institutions - universities, academies, institutes - are called upon to become organizational centers capable of carrying out comprehensive work on development of ethnocultural and ethnopedagogical competencies of future and current teachers. In the Republic of Karelia, this role belongs to the pivotal university of the region - Petrozavodsk State University (PetrSU). Thus, being a member of the International Association of FinnoUgric Universities, PetrSU pays special attention to training of qualified personnel who in the future will transfer knowledge of the languages of the titular ethnic groups of the region - Karelian, Vepsian and Finnish to schoolchildren and university students. So, at the Institute of Pedagogy and Psychology, the Institute of Philology of PetrSU, future teachers study the Karelian, Vepsian and Finnish languages in the following undergraduate programs:

- 44.03.05, Pedagogical education (Bachelor's degree) with two training profiles: "Primary education and education in the subject area of Native (Karelian, Vepsian) language";

- 45.03.01, Philology (Bachelor's degree). Profiles: "Foreign philology" (Finnish language and literature, Vepsian language), "Foreign philology" (Finnish language and literature), "Foreign philology" (Finnish language and literature, Karelian language).

The provided programs are aimed at the linguistic training of qualified specialists: teachers of the national languages of the titular ethnic groups of the Republic of Karelia. Nevertheless, despite the fact that in the course of their training, future teachers necessarily study aspects of ethnocultural education, there are following problems:

- preservation of the languages of the indigenous peoples of the Republic is only one of many, and, unfortunately, an insufficient factor underlying the successful revival of the national cultures of the Karelians, Vepsians and Finns;

- graduating from a university, many graduates cannot fully apply the knowledge gained in practice, do not know how to interest schoolchildren and students in the study of the Karelian, Vepsian, Finnish languages and culture.

As of 2016, 117 students studied Finnish, Karelian and Vepsian languages at the university [17], while in the early 2000s their number was 270 . The indicators are decreasing every year due to the difficulties of studying the Finno-Ugric languages, limited knowledge 
about ethnic culture and its place, its significance for the Republic of Karelia and the Russian Federation. The root of these problems is the insufficient ethno-pedagogical competence of future teachers, namely - ability for ethnopedagogical activity: "A purposeful, motivated set of actions to create conditions for learning, upbringing, development and constructive interaction of students, focused on the all-round development of the personality and preparation for life in modern conditions of a multi-ethnic environment" [18, p. 97].

\section{Discussion of Results}

The above problems can be solved by comprehensively strengthening the educational part of the educational process, thanks to the introduction of disciplines into the training programs of future teachers not only of ethnocultural content, where students receive knowledge about the ethnocultures of peoples living in their region and country, but also ethnopedagogical, which can give the ability to use the received knowledge and teach, using different methods and technologies, ways of assimilating information and students' independent search for knowledge about the national and cultural identity of the "big and small homeland". In recent years, such an approach has been actively included in teaching practice at PetrSU, which makes it possible to make the most effective process of mastering ethnopedagogical competence by future teachers of the Republic of Karelia, which is understood as "the ability to carry out the educational process in a multicultural educational space (...) based on knowledge of the national pedagogical traditions of students" [19, p. 146]. In turn, this contributes to formation of the ethnopedagogical competence of students, which in the future will allow "to ensure the preservation of the value attitude to their own ethnic culture and traditions of folk pedagogy" [11, p. 247]. Here, it shall be noted the importance of students mastering ethnocultural competence as a component of ethnopedagogical competence. This is due to the fact that "ethnocultural competence is considered as a constant, unchanging quality of a person, enriched with knowledge of the spiritual and material wealth of his/her people throughout its historical development, adhering to its ethnic code in everyday life and, if necessary, transferring this knowledge and experience to others" [ 20, p. 76]. Based on the characteristics of both competencies presented in the definitions of the data above, the fact becomes obvious: ethnopedagogical competence is broader than ethnocultural one. The proof of this point of view is that in order to organize the learning process of the younger generations, considering the peculiarities of the ethnoculture of certain peoples, the teacher, first of all, must be familiar with these features. In this case, the fundamental goal of the teacher is the direct assimilation of knowledge about the ethnic diversity of the country, folk cultures, traditions, foundations, rules of behavior, as well as mastering the skills to sing, dance folk works and develop the skills of reproducing handicraft techniques of folk art (for example, sewing costumes, embroidering ornaments). This is due to the fact that "culture of a particular people, ethnic culture is a way of its life; it is its clothing, houses, food, folklore, religious views, beliefs, language, and much more" [21, p. 452]. Only having fully mastered the ethno-cultural competence, the future teacher can create conditions for formation of his/her ethno-pedagogical competence, which will give him/her the right and the opportunity to transfer the knowledge, skills and acquired skills previously mastered by the teacher to future generations of citizens of the state.

Pursuing the task of considering the above parameters, at the Institute of Pedagogy and Psychology PetrSU for students in the field of training 44.03.01. "Pedagogical education", in 2018-2021, the author of the article developed and tested programs of ethnocultural and ethnopedagogical disciplines: "Culture of speech", "Culture of speech and pedagogical rhetoric", "Fundamentals of theatrical and ethnopedagogical activities", "Theatrical and ethnopedagogical activities in primary school". In the course of passing the disciplines, students developed ethnopedagogical competence and, relying on ethnopedagogical 
(folklore, music, painting, crafts) and theatrical (play, training, theatricalization, dramatization) teaching aids used as the root in the structure of the above disciplines, mastered ethnocultural and ethnopedagogical competences by studying the culture and traditions of the indigenous peoples of the Republic of Karelia:

- read literary works (since in the regional culture the folk art culture is the "treasury" of moral, patriotic, aesthetic experience" [22, p. 261]), namely, fairy tales and the KarelianFinnish epic "Kalevala" (after all, "ethnopedagogy (...) recognizes national art and folklore as an important tool for upbringing and education" [23, p. 843]), on the basis of which they studied not only artistic reading, work with the speech apparatus (namely, articulation, diction, since the syllable of national works of titular ethnic groups of the Republic of Karelia is difficult enough to be spoken aloud), but it is also difficult to compose and independently describe psychological portraits of Karelians, Vepsians and Finns, to compare common and distinct character traits (students emphasized "hard work" (Russians, Karelians, Vepsians, Finns); "naivety" (Russians), "craftiness" (Karelians), "suspicion" (Vepsians), "calmness" (Finns));

- studied the features of national non-verbal communication, since "ethno-cultural competence requires strong development of both, - verbal and nonverbal communication" [24, p. 555];

- learned the Karelian, Vepsian and Finnish words that are part of the Russian language, and their pronunciation; compared the origin, meaning and use: kantele (kar. "kantele") - a traditional musical instrument; kodushka (Veps. "kodi" - house) - a house for children; Baltic herring (Finn. "silakka") - fish;

- wrote essays, composed plays of ethnocultural content;

- performed paired and collective speech studies, developing communicative competence;

- staged performances based on works of art by Karelians, Vepsians and Finns, expanding the boundaries of creative and personal potential through independent work on creation of elements of traditional ethnic costumes, fake props (for example, kantele), and make-up.

It is important to note that within the framework of the presented disciplines, theatrical pedagogical means were used to develop the ethnocultural and ethnopedagogical competence of future teachers in order to carry out the learning process interactively, and, therefore, to increase the motivation of students to study aspects related to folk culture. In addition, use of such techniques helps to develop intercultural and, especially, communicative competence, since "the communication component reflects the system and principles of interaction between the subjects of the ethno-pedagogical process on the principles of equality and cooperation, mutual support and assistance"[25, p. 2753]. The effectiveness of this approach in arranging the training of future teachers was confirmed by the data of the experimental work carried out by the author of this study to assess the effectiveness of use of theatrical pedagogy methods in one of the courses presented. It is possible to get acquainted with them in more detail in the article "Theatrical pedagogy as a means of forming the communicative competence of future teachers (based on the discipline "Culture of speech and pedagogical rhetoric")" published in the scientific electronic magazine "Continuing education: XXI century"[26]. It is also necessary to point out here that the key result of the work carried out was to determine the attitude of students to such an organization of the educational process: the students noted the usefulness and informativeness of the disciplines, emphasizing their practice-oriented format, which generally depends on use of theatrical pedagogy methods. Indeed, their inclusion in the structure of other above-mentioned disciplines studied by students shows that future teachers express their desire to improve in the direction of ethnocultural and ethnopedagogical education. Moreover, they actively use the materials, knowledge, skills and abilities gained during practical classes during the period of pedagogical practices, within which they show not only the degree of mastering the skills of speech culture and the ability to arrange ethnopedagogical activities using theatrical 
pedagogical techniques, but also the level of general cultural and linguistic (oral, written) erudition of ethnocultural content.

Therefore, there is no doubt that implementation of ethnocultural education requires the training of qualified personnel at all levels of the educational system. Therefore, the basis for accentuation of the ethnocultural tendency of teaching at PetrSU is the study of disciplines of ethnocultural content not only by future school teachers, but by higher school teachers. The need for mastering ethnocultural and ethnopedagogical competences by students of pedagogical directions at the bachelor's or master's level is clear, but they can and shall be formed at the level where students are simultaneously represented in programs of different areas of training, namely, at postgraduate education.

Having mastered the third level of higher education in Russia - postgraduate studies students receive the qualification "Teacher. Teacher-researcher", which in the context of implementation of their professional activities obliges them to possess ethnocultural and ethnopedagogical competences. This is confirmed by the fact that in a modern university, thanks to the international mobility of students and the technological capabilities of arranging distance study, the tendency for development of ethnocultural education has become stronger every year. Considering these facts, the postgraduate students of PetrSU study the discipline "Socio-cultural situation and trends in development of education" developed by T.A. Babakova - Doctor of Pedagogy, Professor of the Department of Theory and Methods of Higher and Professional Education at the Institute of Pedagogy and Psychology. The simultaneous teaching of this discipline to students of different areas of training is its main advantage. Regardless of the specialty - exact or humanitarian, - the future teacher of higher education masters many competencies, the main of which is UK-1: the ability to critically analyze and evaluate modern scientific achievements, generate new ideas when solving research and practical problems, including in interdisciplinary fields. This is important, since a future teacher of higher education, while studying this discipline, learns to conduct a comparative analysis of the already existing knowledge and skills from his/her field, for example, from the point of view of its cultural significance for the ethnos.

Joint study of the modern socio-cultural situation, the main trends in development of education in the world and in Russia ensures interdisciplinary and intercultural interaction of representatives of different scientific fields. This allows future teachers to exchange views during practical classes, to discuss acute issues of cultural (including ethnic) development of the domestic society, to look for the right ways to express and convey ideas to the interlocutor so that the discussion takes place in conditions of tolerance and mutual respect that can be created only with possessing entocultural knowledge. Moreover, the knowledge gained helps students to select and use optimal teaching methods, which, in a multicultural educational environment in higher education, are important: they allow not only to build a teaching strategy considering the entocultural characteristics of the student group, but also improve the ethnopedagogical skills of graduate students as future teachers. The study of this discipline is aimed at forming students' ideas about the trends in development of education in the context of the peculiarities of the modern sociocultural situation and sets itself the following tasks:

- to ensure assimilation by students of knowledge about the positive and negative features of development of the modern socio-cultural situation;

- to convey to future teachers of higher education knowledge about the essence and ways of implementing modern trends in development of education: globalization, internationalization, transnationalization, continuing education, diversification of education, informatization of education, humanization of education, competence-based approach in education, technological approach in education, active and interactive learning, education for sustainable development, environmental education, inclusive education [27]. 
It is interesting that the study by future teachers of higher education of the ethnocultural trend in development of education resonates with the trends indicated above, since, for example, it is connected:

- with the processes of globalization in the world and serves as a counterbalance for the unifying educational systems, because it focuses on the search for national and cultural characteristics of ethnic educational activities;

- humanization of education, since adheres to the basic principle of ethnopedagogics formulated by its founder, G.N. Volkov - "education in ethnopedagogics determined through example and love, and the person - in loving education, nurturing" [28, p. 194];

- environmental education, as it indicates: a) the importance of limiting the technogenic impact on human life, when "ecology stops to be the problem of separate cities, countries and becomes global" [29, p. 260]; b) the need to arrange the learning process in accordance with the natural environment and embed it in a stable ecosystem, the basis of which is built considering the ethnic characteristics, and etc.

Therefore, ethnocultural education in the Republic of Karelia is largely carried out thanks to implementation of the national-regional component of education by educational institutions of the region. Nevertheless, it is worth pointing out that, although a smaller, but important share in development of ethno-cultural education and upbringing belongs to the national-cultural events and holidays held in the Republic, as well as thanks to tourism.

Karelia annually hosts: the traditional fish festival "Kalakunda", a festival of humor in one of the oldest villages of the Republic "Kindasovo"; tourists traditionally visit the House of Kantele, the island of Kizhi, the village of Kinerma, where they learn a lot of new and interesting things about the culture of the peoples living in Karelia, their history, values and traditions. These tourist routes were created in the Republic of Karelia recently and are developing thanks to the activities of the Petrozavodsk State University, whose students study in areas 43.03.02 "Tourism", 46.03.01 "History" (profile: "History. Historical and Cultural Tourism") in the process of implementing educational activities of a practical nature take an active part in identifying and developing tourist sites, routes, arranging the events of national and cultural content. Thus, future professionals in the field of tourism and history acquire ethnocultural and ethnopedagogical competence, because their activities, in general, are of an educational nature. As an example of the achievements of students in this direction, one can cite a project of excursion along the ecological-patriotic trail "Height 152.6" in the capital of the Republic of Karelia, Petrozavodsk, developed by them. The goal of the project is patriotic education (the trail is landscaped in the City Defenders Park created in honor of the soldiers who fought during the Finnish occupation of Petrozavodsk in 1941) and the study of the nature of Karelia. To achieve it, the students developed a route plan of the trail so that during the excursion participants could get acquainted not only with the history of their native land, but also with the inhabitants of the park, "enjoy the pristine nature, fresh air and unity with the flora and fauna, without leaving outside Petrozavodsk" [30]. This is another indicator of the possibilities for interaction of ethnocultural and environmental trends in education, which was mentioned above when comparing the ethnocultural trends in development of education with others.

Thus, the activity of PetrSU students clearly shows the ability of the education system to form an environment for familiarizing the inhabitants of the Republic of Karelia with the ethnoculture of the region and serves as an example of development of ethnocultural tourism, which since 2020 is a priority in the development of national projects of the country [31], which in turn creates additional conditions for implementation of the trend of ethnocultural education. 


\section{Conclusion}

In general, the experience of the Republic of Karelia shows the ways and options for development of the trend of ethnocultural education. The example of Petrozavodsk State University shows how the educational system integrates with other social institutions in order to create an ethnocultural and ethnopedagogical environment for development of ethnocultural education. In addition, the experience of the university shows that such activities are possible at all levels of education, since in higher education the ethnopedagogical component is especially important, because thanks to the organization of ethnocultural education and enlightenment, the comprehensive development of ethnocultural life in the region is carried out in order to preserve and enhance the multinational flavor of Russian society. This is ensured thanks to the high-quality training of professionals with ethnocultural and ethnopedagogical competence.

Within the framework of this study, it was possible to clarify the difference between these terms, which lies in the fact that the ethnocultural component is included in ethnopedagogical competence, and, therefore, allows us to establish that ethnocultural competence is already ethnopedagogical. In addition, the study of formation of ethnocultural and ethnopedagogical competencies showed that this process is carried out more efficiently, if it is arranged with inclusion of the ethnocultural and ethnopedagogical content of the methods of theatrical pedagogy in the structure of educational disciplines. In turn, this determines the prospects for a thorough study of the possibilities of integrating the means of ethnopedagogy and theatrical pedagogy. Also, the determining factor in the study is the conclusion: in ethnocultural education, it is important to pay special attention to not only ethnocultural, but also ethnopedagogical competence, since the latter determines the factors of creating conditions for the training of qualified specialists who are able to implement the successful transfer of ethnocultural knowledge and skills to future generations.

\section{References}

1. A. B. Afanas'eva, Etnokul'turnoe obrazovanie: sushchnost', struktura soderzhaniya, problemy sovershenstvovaniya, Znanie. Ponimanie. Umenie, 3, 189-195 (2009)

2. Ni Negan Selasih, Education Based on Ethnopedagogy in Maintaining and Conserving the Local Wisdom: a Literature Study, Jurnal Ilmiah Peuradeum, 2, 293-306 (2018)

3. Demografiya. CHislennost' i sostav naseleniya (2021). Access mode: https://rosstat.gov.ru/folder/12781

4. Social'no-demograficheskij portret Rossii: po itogam Vserossijskoj perepisi naseleniya 2010 g. (2012)

5. Konstituciya Rossijskoj Federacii s gimnom Rossii, 43 (2020)

6. T. M. Shukaeva, Etnokul'turnoe obrazovanie v usloviyah vvedeniya FGOS, Evrazijskij Soyuz Uchenyh, 3 (24), 154-155 (2016)

7. Rossijskaya Federaciya. Zakony. Ob obrazovanii v Rossijskoj Federacii (2020)

8. V. Putin, Rossiya: nacional'nyj vopros (2021). Access mode: http://www.ng.ru/politics/2012-01-23/1_national.html

9. N. Afanasev, Ethnocultural Self-Determination of Students in the Educational Environment of the University, Atlantis Press: Advances in Social Science, Education and Humanities Research, 374, 271-275 (2019)

10. A. M. Cirul'nikov, Sociokul'turnye osnovaniya razvitiya sistemy obrazovaniya, Voprosy obrazovaniya, 2, 40-65 (2009) 
11. T. A. Shergina, Etnokul'turnoe obrazovanie uchitelej dlya malokompletnyh shkol Arktiki, Perspektivy Nauki i Obrazovaniya, 2 (32), 246-251 (2018)

12. M. V. D'yakonova, Sovremennyj status $i$ perspektivy revitalizacii finno-ugorskih yazykov $v$ Respublike Kareliya, Ezhegodnik finno-ugorskih issledovanij, 156-167 (2016)

13. Naselenie po nacional'nosti i vladeniyu russkim yazykom po sub"ektam Rossijskoj Federacii, Statistika Rossii (2012)

14. Yu. N. Tril, Nacional'nye obryady i etnokul'turnoe obrazovanie, Vestnik Majkopskogo gosudarstvennogo tekhnologicheskogo universiteta, 1, 1-5 (2016)

15. Zakon $\mathrm{RK}$ «O gosudarstvennoj podderzhke karel'skogo, vepsskogo i finskogo yazykov $\mathrm{v}$ Respublike Kareliya. Access mode: $\underline{\text { http://karelia- }}$ zs.ru/zakonodatelstvo_rk/prav_akty/759-zrk/

16. M. I. Bagautdinova, Polikul'turnoe $i$ etnokul'turnoe obrazovanie $v$ sovremennom obshchestve, Vestnik Tuvinskogo gosudarstvennogo universiteta, 4, 108-112 (2013)

17. V PetrGU finskij, karel'skij i vepsskij yazyki uchat 117 chelovek (2016). Access mode: http://nazaccent.ru/content/19615-v-petrgu-finskij-karelskij-i-vepsskij.html

18. M. I. Gubanova, Organizaciya etnopedagogicheskoj deyatel'nosti v shkole po socializacii uchashchihsya, Privolzhskij nauchnyj vestnik, 8 (36), 96-98 (2014)

19. T. L. Guruleva, Pedagogicheskie tekhnologii integracii inostrannyh studentov $v$ obrazovatel'noe prostranstvo VUZa (na primere studentov KNR), Vysshee obrazovanie v Rossii, 3, 144-153 (2016)

20. B. A. Tahohov, Formirovanie etnokul'turnoj kompetetnosti uchashchihsya v kontekste globalizacii, Science for Education Today, 4, 73-92 (2019)

21. H-o. D-N. Oorshak, Ethnic Culture and Value System of Students (Based on the Material of the Republic of Tuva), Journal of Siberian Federal University. Humanities \& Social Sciences 3, 7, 451-456 (2014)

22. L. V. Dyomina, Etnokul'turnoe obrazovanie - regional'nyj komponent, Vestnik TGU, 3 (83), 258-263 (2010)

23. R. Toleubekova, The Role of Ethnopedagogy in Shaping Positive Attitudes Towards Traditional Values of Kazakh People among Master's Students Majoring in Education in Kazakhstan, Problems of Education in the 21st Century, 6, 834-846 (2018)

24. G. T. Stefanenko, Etno-Cultural Competence as a Component of Competence in Communication, Psychology in Russia: State of the Art, 3 (1), 550-564 (2010)

25. Sh. Arsaliev, Ethno Pedagogical Technologies in Regional Education Environment, The European Proceedings of Social \& Behavioural Sciences (EpSBS) (2019)

26. A. O. Suhov, Teatral'naya pedagogika kak sredstvo formirovaniya kommunikativnoj kompetentnosti budushchih pedagogov, Nepreryvnoe obrazovanie: XXI vek, 1 (29), (2020)

27. T. A. Babakova, Sovremennaya sociokul'turnaya situaciya $i$ tendencii razvitiya obrazovaniya (2017)

28. G. N. Volkov, Etnopedagogika kak pedagogika nacional'nogo spaseniya, Sibirskij pedagogicheskij zhurnal, 1, 194-198 (2004)

29. Z. A. Khusainov, Education of Ecological Culture of Schoolchildren on the Basis of Ethno Pedagogy, Life Science Journal, 9, 260-264 (2014) 
30. Proekt ekologo-patrioticheskoj ekskursii po Petrozavodsku predstavili studenty PetrGU (2020). Access mode: http://rk.karelia.ru/social/proekt-novoj-ekskursii-popetrozavodsku-predstavili-studenty-petrgu/

31. V. Putin zayavil, chto mery po razvitiyu etnokul'turnogo turizma nuzhno vklyuchit' v nacproekt (2020). Access mode: https://tass.ru/obschestvo/11028317 